\title{
4 Clusters of Prestige: Social Media and Social Order in the Norwegian Bible Belt
}

\author{
Stefan Fisher-Høyrem and David Herbert
}

\subsection{Introduction}

This chapter uses data from the southern Norwegian city of Kristiansand (population 90,000), asking whether social media constitute a vector for challenging the local social order, or rather reproduce and reinforce existing established-outsider relations. We combine computational and qualitative methods, while drawing on analytical concepts from Norbert Elias' figurational sociology, whose primary concern is how social figurations are created and maintained through notions of prestige and shame, as well as models of behavior (Elias, 1978). Specifically, we utilise Elias' conceptualization of "established-outsider relations," which he proposed as "a universal human theme" of creating and maintaining social distinctions within the same community (Elias, 1994, p. xv).

For Elias, the fundamental characteristic of social figurations is the distinction between a dominant "established" group and other "outsider" groups; indeed, categories such as gender, race, or class he sees as secondary to this most fundamental social figuration (Elias, 1994, p. xviii). ${ }^{5}$ The superiority of the established group stems not primarily from numerical size or use of force - the group is often a numerical minority - but from a comparatively high degree of internal cohesion and extent of communal control (Elias, 1994, p. 86). Internal cohesion is created and maintained by certain collective norms "which are apt to induce the gratifying euphoria that goes with the consciousness of belonging to a group of higher value and with the complementary contempt for other groups" (Elias, 1994, p. xviii). Put another way, the two key elements in established-outsider figurations are power and morality, or rather, power reinforced by a sense of moral superiority (Elias, 1994, p. xv).

Elias's framework lends itself particularly well to analyses of social media, since they are constructed precisely to facilitate mutual recognition (or ignoring) between users competing for signs of prestige and seeking to reinforce their social status within particular networks and groups.

5 For a discussion of Elias' theory of established-outsider relations and race, see e.g. (Stanley, 2016). 


\subsection{Social Order in Kristiansand}

In the following, we propose that Kristiansand's social order includes a powerful 'established' network of businesses, politicians, and other influencers explicitly or implicitly affirming hetero-normativity, nuclear family values, sports and outdoor life, and a loose mix of 'conservative' Evangelical Christianity and mercantile interests. While this group might be numerically inferior, its norms are reproduced and made manifest across a range of social fields, such as the promotion of the city as a whole as well as new neighborhoods, the field of cultural production, and public rituals.

\subsubsection{Evangelical Church Culture}

Named the buckle of the Norwegian bible belt, Kristiansand is the administrative and economic center of the country's southernmost region - a region which for the past century has been known as a stronghold of conservative Evangelical Christianity. The close association between regional Christian mission ministries, free churches, and the mercantile middle and upper classes has molded the political, religious, and cultural landscape of the region and its coastal 'capital' for at least the past 120 years, and is well-known and accounted for by historians. (Abrahamsen, 2014; Seland, 2012, 2014). Even today, the region - but in particular Kristiansand - remains something of a national political anomaly in its comparatively strong support for the relatively conservative Christian Democratic Party (KrF), together with weaker support for the Labour Party (AP)(Røed, 2010). Many of the Christian families who, with the help of willing and generous brothers in the Christian associations, became wealthy during the late nineteenth and early twentieth centuries, still remain so today. ${ }^{6}$

Through the 1990s and onwards, the region and its municipal center has maintained a high level of religious activity according to almost all common indicators (Botvar et al., 2010; Botvar \& Aagedal, 2002; Magnussen et al., 2013). 24\% are religiously active at least once a month, compared to $7 \%$ nationwide. The region has a high proportion (15\% in 2008) of people who feel some association with one of its many free Evangelical churches, compared to the rest of the country (3\% in 2008) (Magnussen et al., 2013). The region has high levels of part-time work among women, and studies suggest an ideal of "the good mother" - working less in order to "spend time with her children" - remains a strong norm, to the point where nonworking mothers might sanction other mothers who "work too much," which again leads to full-time-working mothers reporting feeling like outsiders (Magnussen et al.,

6 As Elias also points out, it is not uncommon to find a certain allusion to family bonds in studies of high- and upper middle-class communities, where networks of families often may operate as a powerful factor in the social stratification and structure of the local community (Elias, 1994, p. 3). 
2005).There are more married couples with children than in other regions, and more married couples with many children (Ryen, 2002).

Other research has shown how in this particular region the most important factor explaining the lingering skepticism towards gender equality - even more than social background, age, education, or income levels - is the conservative Christianity found in the free churches and associations (Magnussen et al., 2005, 2013). So-called 'traditional men' in this region are more conservative than their peers in other parts of Norway: they believe in God; they tend to see religion as relevant and important on a daily basis; they support religious organizations, and they are particularly oriented around so-called 'traditional family values'. While on a national scale this group tends to score low on experience of contentment/happiness, in this region it scores the highest, enjoying higher social status, higher education, and a stronger financial situation (Ellingsen \& Lilleaas, 2010).

Even religious people in the region who are "sporadically active" are more conservative than the same group nationwide, which some researchers have suggested "supports the hypothesis of a Christian conservative hegemony" (Halvorsen, 2004). Some have suggested that the effects of conservative Christianity extend beyond the "core congregation," so that conservative values (with regard to family structures, sexual norms, and so on) somehow spill out of the specific church contexts. While one might contest this by saying it ascribes too much power to what is arguably still a numerical minority, Elias' theory of established-outsider relations explains how the fact that key members of the "established" group might hold key positions in the community means that their norms come to influence people beyond their relatively close-knit circle, and despite their lacking numbers. Indeed, it has been shown that the moral ideals associated with this group remain strong even for people who have to some extent left the former religious faith; that is, the ideals continue to influence their perspective on what it might mean to be a "good person" and lead a "good life" (Henriksen \& Repstad, 2005).

\subsubsection{Family Friendly}

From the 1930s, tourism gradually became one of the region's primary economic engines, with Kristiansand as a natural center point. During the first decades of the twentieth century, as artists began to explore the variations in the southern landscape, these traits gradually turned into "positive" stereotypes in the increasing promotion of Sørlandet (the South land) and Kristiansand as a tourist attraction associated with summer, seaside, and hospitable locals (Johnsen, 2010). The accusations that had been levelled at southerners during the decades of decline in the sail shipping industries - that they were slow, lacked initiative, and were generally politically incompetent - transformed into characteristics with more positive connotations: the 
stereotypical southerner (and Kristiansander) was now portrayed as relaxed, calm, and unassuming (Hundstad, 2008).

From the early 2000s, an image of positive homeliness took a particularly strong hold of the promotion of the city as an object of tourist consumption, mainly following the lead of the regional tourism and business cluster USUS's project The Children's City. Tourist brochures began showcasing sunny archipelagos, children laughing and swimming, and happy families visiting the local zoo and amusement park Dyreparken. In an interview, one former project leader at USUS described how this project gradually incentivized businesses not usually catering to families with children to find ways of doing so. She recounted the story of a local bar and bistro owner who, when hearing of the project, exclaimed "Oh God, if we don't accept children in here, we'll lose all of our summer business!"

Kristiansand's self-promotion can also be understood in relation to urban policy development in the field of cultural production, in particular the foundation Cultiva and its surrounding debates. In 2002, the municipality sold portions of its share in the local water power plant Agder Energi to a state-owned company, and set up the public foundation Cultiva with a NOK1.4 billion trust fund of which the returns are to be used to support the city's cultural economy. As the first and only of its kind in Norway, Cultiva emerged as "the principal cultural entrepreneur in the city of Kristiansand, seeking to play a pro-active role also in the financial and industrial sector[s]" (Lysgård \& Tveiten, 2005, p. 498). As such, it became subject to extensive public debate, in particular regarding its stated purpose and underpinning ideology (Bille, 2013; Lysgård, 2013). In 2005, researchers Lysgård and Tveiten put it thus:

Kristiansand is a small town with a traditional bourgeoisie citizenship marked by a Nordic brand of Christian-democratic political values. Experimental art, avant-gardism and political critique have not been in the forefront of this culture. The moral-based and traditionalist concept of culture accepted as legitimate in the bourgeois and religious parts of the city's cultural life is, therefore, challenged by Cultiva, and has led to a discussion about how the money should be spent and by whom. This is actually a question about who should control the power of the cultural discourse in the city, the discourse about what is acceptable according to ethical and moral values. The broad, liberal and innovation-oriented concept of culture adapted by Cultiva where culture is meant to 'put economy to work' is challenging the more or less hegemonic traditionalist discourse of culture in the city of Kristiansand (Lysgård \& Tveiten, 2005, p. 496).

At the time of writing, one long-time member of the Cultiva steering board is Kristiansand's vice mayor from the conservative Christian Democratic party. In 2009, another well-known conservative Christian politician from the Conservative Party became new chair of the board. Soon after, in April 2011 Cultiva surprisingly changed their official strategy to the following: "Kristiansand will become the leading city of culture for children in the Nordic countries. With this the city will become the best place for growing up and a city that children and their families alike must visit" (About Cultiva, 2017). Instead of having artists apply for funding (a process that had 
been criticized for being overly complex and oriented towards questions of economic profitability), the board would seek to initiate projects themselves, and then look for potential partners. The abrupt change spurred strong negative reactions from the cultural milieus in the city - like when more than 50 artists, critics, actors, and directors issued a joint statement protesting the change and demanding the board members' resignation - but at the time, these protests had little effect.

\subsubsection{Physical Activity}

Kristiansand's self-promotion and image-building is equally evident in the marketing of new neighborhoods. Perhaps the largest and most widely advertised new development since 2015 is the area of Lauvåsen. Primary targets are families with parents aged 35-45 with an average of 1.7 children. According to the project leader, a competing project run by another developer had already taken the slogan "The Children's Neighborhood," so they decided to make theirs "the Sportiest Neighborhood in Norway." Houses include extra storage space for sports equipment, and a new $5 \mathrm{~km}$ running track (parts of which will be fitted for parents walking with prams) is being prepared in the surrounding woods. Everyone moving to the neighborhood will receive free membership at the local gym.

In general, the population in Kristiansand appears to value physical activity and exercise. The city has seen impressive growth since the 1970s in the area of sports and outdoor life. While this has been a general development on a national level, historians have pointed out that in the southern region one important factor was the free churches' change in attitude, from viewing sports as "worldly" and potentially damaging to the faith, to supporting physical exercise and the importance of visible Christian 'role models' in various social fields. In the following decade many sports clubs saw such a dramatic increase in Christian members that some of them - like the main football club IK Start - even came to be seen as "Christian clubs" (Justvik, 2012). ${ }^{7}$

At the time of writing, Kristiansand boasts over 110 local sports clubs, and near 60,000 memberships (many are members of two or more clubs) after a $28 \%$ increase over the past decade, primarily in football, handball, swimming and gymnastics. The same decade similarly saw a strong increase in physical exercise across generations. Of the ten largest cities in Norway, Kristiansand has the highest coverage of sports centers and arenas per capita (Kommunedelplan Idrett- Og Friluftsliv, 2015-2018, 2014). Local businesses and even the city council sponsor the national population health project Cycle to Work, enabling Kristiansand's citizens to participate for free. In 2014,

7 IK Start still enjoys an annual Church service in their honor at the local church. 
participation had reached a national record high of 10\%, five times higher than other comparable cities.

\subsubsection{Characteristics of Kristiansand's Social Order}

From the above we might glean some general characteristics of Kristiansand's social order.

One characteristic is a particular church culture. During interviews with project leaders and key people found through "snowballing" methods, remarkably many informants referred to "church culture" or "church power" as a key factor in the city's social order. These were less precise attributions than expressions of a general sense that in Kristiansand it matters whom you know, and that decisions can often appear to have been made after church services as much as around official negotiation tables.

Another characteristic is a strong focus on nuclear families. We see it in how the Children's City project not only seeks to cater to this demographic for tourism purposes, but also in the effect it has on local businesses, who even outside of the tourist season have to target families with children, even if this would not be their 'natural' customer base. A further indication is the changes made to Cultiva's statement of purpose, which at the time when this research was conducted primarily targeted nuclear families with children.

A third characteristic we see across various arenas in Kristiansand is a general celebration of physical exercise and experiencing nature. This is evident in the high number of memberships in sports clubs, and in the mediatization of and official subsidizing of fitness events such as Cycle to Work or Terrengkarusellen. Similarly, the promotion of a large new neighborhood as "the sportiest neighborhood in Norway" speaks to the importance of physical exercise as a symbol of prestige and high status.

In isolation, none of these are peculiar to Kristiansand; many cities promote themselves in similar ways. However, we contend that the particular combination of these gives Kristiansand's social order a distinct local "flavor" which is recognizable as "typical" of the place. In the next section, we turn to the question of whether social media in Kristiansand tend to challenge these norms, or rather serve to reinforce and reproduce them.

\subsection{Social Media in Kristiansand}

Social media are frequently imagined as vectors of transformation and disruption, and as a result very little existing research considers the continuities and conservative schemas that are reproduced by these platforms (Benkler, 2007; Castells, 2008). It is often overlooked how algorithms reward engagement in the form of likes, comments, 
mentions, referrals, and so on, which means that online visibility depends on affirmation, and that different forms of affirmation provide different levels of visibility. In contrast to such accounts, Alice E. Marwick convincingly argues that just like the tech-entrepreneurial scene in San Francisco where they were first designed, "social media applications encourage people to compete for social benefits by gaining visibility and attention [...] adopt[ing] self-consciously constructed personas and market themselves [...] to an audience or fan base" (Marwick, 2013, p. 5). One point being made here is that the technology itself is structured in order to create and facilitate ever-more conforming clusters of users with similar sensitivities and aspirations. In these clusters, most signs of affirmation go to a few very active and comparatively central users with a lot of followers. Receiving affirmation from a cluster of users, or indeed from one central user within such a cluster, ensures visibility within that cluster.

Again, Elias' figurational sociology lends itself particularly well to this reading of social media logics. In his book The Court Society (1983), he describes the social life at the seventeenth-century royal court, which has several striking parallels to the social dynamics on social media platforms. For instance, in order to rise in the social hierarchy of the court, the important thing is not so much to be rich and powerful, as to be perceived as such. ${ }^{8}$ People at the center of this universe display their status with ever-new attire and performances, which people in their orbit seek to emulate and mimic. In the same way, social media users tend to orbit central celebrity users - so-called influencers - within specific fields of interest that one simply has to follow in order to belong.

Furthermore, like at the royal court, social media users tend to display themselves in situations signaling high status, while at the same time trying to stand out from the crowd as authentic and original. Success in this endeavor is relative to feedback in the form of likes, comments, tags, shares and mentions. This "traffic" makes users visible to others, just as their own affirmative gestures determine what and who will (over time) become visible and available to them. Negative feedback most often takes the shape of scrolling past content, unfollowing, or quietly ignoring - though outright shaming also occurs.

Drawing on these theories, the Cultural Conflict 2.0 project has sought to investigate how social media is reshaping social relations in particular cities, looking especially at how social order is generated, reinforced, and challenged both on social media platforms and at their intersection with life in the physical city. What then can be said about the social order and social media in Kristiansand? We began our investigation by focusing on Instagram, because this platform's strong emphasis on visual communication and affirmation in the form of following, likes and affirmative comments, together with a comparatively limited possibility for verbal messaging,

8 I am grateful to Justus Uitermark and John Boy for highlighting this point. 
means it lends itself particularly well to this kind of analysis. With Instagram we were able to combine interviews with computational methods, as we had formerly done in Amsterdam (Boy and Uitermark, 2016). In addition, and on a more practical note, this data was freely available before the platform was acquired by Facebook in June 2016.

\subsubsection{Local Clusters}

In order to locate user networks and clusters, we identified geotagged posts from Kristiansand posted between June 2015 and May 2016, from users who post at least every 14 days (to eliminate potential tourists). We assigned a relational tie every time users expressed mutual appreciation in the form of likes, comments, mentions, tags, and so on. In this way, we identified 8 Instagram user clusters in Kristiansand, each centering on about 10-15 top users. The pattern of distribution of social status typical of Instagram also holds on this level: most likes and comments go to the top users, who could be seen as modelling the successful symbolic entrepreneur in their respective clusters.

We manually viewed all the posts posted in this period by the ten top users in each cluster and compared each of their feeds against ten randomly selected users in the same cluster. Most of these users had an open account, so we were able to see all their posts. The few who had private accounts generally seemed (from the look of profile pictures, or from emojis or hashtags used in their bio) to affirm the general sense of their respective clusters' circulating symbols of prestige (so, for instance, a private account near the top of a cluster focusing on CrossFit might typically have a profile picture of someone performing CrossFit exercises).

Table 4.1 below shows the eight largest clusters, the name we gave the cluster according to the typical themes that circulate among its most central users, the clusters' size in terms of connected users, their top tagged locations, and which businesses were found among the top ten users. Names of businesses related to specific informants have been changed for the sake of anonymity.

\subsubsection{Local Top Users: Navigating Hierarchies}

We located the ten most connected users in each cluster. Some of the top user profiles were businesses or hub accounts where several users share photos in specific genres (like in C1). Some users were 16 or younger (like most top users in C4), while others had since moved to other cities. We contacted three randomly selected top users with open profiles in each cluster. We also contacted some users who were most connected across the city as a whole, even if they were not prominent in any one cluster. Most responded, but some refused to be interviewed - though a few changed their mind 
when learning that they had been selected among local top users. In total, we ended up interviewing 12 Instagram users, 10 of which were randomly selected top users. Most were interviewed face to face, though two were interviewed via Skype. In the following their names (and the names of associated businesses, if any) have been changed.

Table 4.1: Overview of the eight largest clusters obtained from community detection on relations among Instagram users in Kristiansand.

\begin{tabular}{|c|c|c|c|c|}
\hline Number & Cluster & Size & Top tagged locations & $\begin{array}{l}\text { Businesses among top } \\
\text { users }\end{array}$ \\
\hline $\mathrm{CO}$ & $\begin{array}{l}\text { Unclustered } \\
\text { users }\end{array}$ & - & $\begin{array}{l}\text { Dyreparken; Scandic Kristiansand } \\
\text { Bystranda; Kilden Teater- og } \\
\text { Konserthus; Vågsbygd, Kristiansand; } \\
\text { Sørlandssenteret }\end{array}$ & $\begin{array}{l}\text { Kristiansand Avis; } \\
\text { Moods of Norway, } \\
\text { Sorlandssenteret; NRK } \\
\text { Sorlandet; }\end{array}$ \\
\hline $\mathrm{C} 1$ & $\begin{array}{l}\text { General } \\
\text { cluster }\end{array}$ & 762 & $\begin{array}{l}\text { Vågsbygd, Kristiansand; Hamresanden; } \\
\text { Flekkerøya, Kristiansand; Flekkerøy; } \\
\text { Lulu's }\end{array}$ & \\
\hline $\mathrm{C} 2$ & $\begin{array}{l}\text { Event } \\
\text { cluster }\end{array}$ & 509 & $\begin{array}{l}\text { Vågsbygd Videregående Skole; } \\
\text { Vågsbygd, Kristiansand; Flekkerøy; } \\
\text { Dyreparken; Flekkerøya, Kristiansand }\end{array}$ & \\
\hline C3 & $\begin{array}{l}\text { Fashion } \\
\text { cluster I }\end{array}$ & 307 & $\begin{array}{l}\text { Flekkerøy; VOLT Sandens; Berglihn } \\
\text { Gullsmed; Flekkerøya, Kristiansand; } \\
\text { Bønder i Byen }\end{array}$ & \\
\hline $\mathrm{C} 4$ & $\begin{array}{l}\text { Church } \\
\text { cluster I }\end{array}$ & 304 & $\begin{array}{l}\text { Vågsbygd, Kristiansand; Vågsbygd } \\
\text { Videregående Skole; Flekkerøy; } \\
\text { Flekkerøya, Kristiansand; Fiskebrygga }\end{array}$ & \\
\hline $\mathrm{C} 5$ & $\begin{array}{l}\text { Fitness } \\
\text { cluster }\end{array}$ & 301 & $\begin{array}{l}\text { Viking CrossFit; Spicheren } \\
\text { Treningssenter; Emijoly Yoga \& Pilates; } \\
\text { Power CrossFit; Power CrossFit KRS }\end{array}$ & Viking CrossFit \\
\hline $\mathrm{C} 6$ & $\begin{array}{l}\text { Fashion } \\
\text { cluster II }\end{array}$ & 295 & $\begin{array}{l}\text { Vågsbygd, Kristiansand; Fiskebrygga; } \\
\text { Odderøya; Jordbærpikene Sandens; } \\
\text { Baneheia }\end{array}$ & \\
\hline $\mathrm{C7}$ & $\begin{array}{l}\text { Outdoor } \\
\text { cluster }\end{array}$ & 248 & $\begin{array}{l}\text { Odderøya; UIA Universitetet i Agder; } \\
\text { Hamresanden; Baneheia; Vågsbygd, } \\
\text { Kristiansand }\end{array}$ & \\
\hline $\mathrm{C} 8$ & $\begin{array}{l}\text { Church } \\
\text { cluster II }\end{array}$ & 233 & $\begin{array}{l}\text { Flekkerøy; Pentecostal Church; } \\
\text { Vaya con Dios Coffee Shop; Bohem; } \\
\text { Flekkerøya, Kristiansand }\end{array}$ & \\
\hline
\end{tabular}


Local top users boast between 1,000-2,000 followers (though not all of these are local), while they themselves follow less than half this number. Most of them spend at least one hour editing photos (always taken with phone camera or digital camera, never the Instagram camera function) before they post them, and most of them use the VSCO app for editing. They also have some idea (more or less substantiated) about how or when one should post to generate higher levels of engagement.

We found that top users navigate two social worlds simultaneously that in some respects work according to different logics. On the one hand, there is the exclusive online-only community of Instagram. Here, they actively seek affirmation from influencers at the top of the hierarchy in specific lifestyle areas, such as physical exercise, fashion, foods, etc., whose presentation style they try to emulate, and whose affirmation they actively seek.

For instance, top users Erik (27) and Sonja (25) in the Fitness cluster (C5), both active at the Viking CrossFit center, seek out world leading CrossFit performers in order to follow them. On average, Erik's posts receive around 500 likes. But on a post featuring himself and a particular CrossFit influencer, he has received over 1,800 likes.

Erik: "I got 1,600 new followers in one day. That's pretty cool [...] all their followers came over to me."

Similarly, Beate (28) uses the platform to showcase photos of architecture or natural landscapes. She deliberately seeks out influencers within these genres, and occasionally receives acclamation from them. Over time, she says, she has developed a sense of what specific influencers (and their followers) might affirm.

Beate: "Like this building [...] I spent 20 minutes just getting the angle right. Here, [the influencer's] response means a lot [to me], because I put so much effort into it.”

But this online-only exclusive "royal court" is not the only one the local top users navigate; there is also the world of personal friends, and the signs of affirmation that circulate in local on- and offline networks. Here, users police each other (and themselves) according to unwritten but strict codes of prestige and shame, where the fear of being ignored is more significant than the fear of explicit negative response.

Beate (28), a top user in the Church cluster (C8), engages in political work, but avoids politics on her Instagram profile because her friends might not be interested. As one of the most connected users across the city as a whole, she puts strict demands on herself regarding what she posts or likes and spends a lot of time finding the hashtags that she believes will bring influencers to her profile. Yet for local friends not part of the genre-specific community, she operates with a different set of criteria.

Beate: "[If] a friend posts a picture, then I like that picture regardless of what it is. Because I like my friends, and if they post it, then it's important to them, I reckon.” 
Other top users similarly speak of liking all their friends' posts, even the posts they dislike. Ragnhild (19) spoke of her own criteria for liking posts.

Ragnhild: “I like a lot of posts. To me, that's a way of supporting people [laughs], like 'Nice pic!,' even if I don't think it's a good picture, I... well, we're friends, so...”

Jon (38) feels his pastoral responsibilities in a local free church prevent him from unfollowing users that he knows offline, even if he dislikes their posts.

Jon: “I’m the kind of guy who's worried about hurting people's feelings. If I unfollow someone, I feel so awkward [laughs]. So... I've never done that.”

Visibility in the respective worlds - online lifestyle networks and local personal friends - in both cases depends on engagement and active affirmation. If more engaged in one world, our informants will gradually become less visible in the other. For instance, engaging too much with friends' posts even if these are irrelevant to their online lifestyle communities means that their friends' posts will become visible to users in the more prestigious online communities, which might result in them unfollowing our informants, practically rejecting them from the hierarchy they are trying to ascend. However, ignoring friends' posts in order to preserve one's position in the online hierarchy means an increased risk of having to explain oneself to those friends offline.

Several informants have examples of instances where they, having initially "liked" a picture they would otherwise consider inappropriate, later confronted the friend face to face about it. Maria's (19) friend, for instance, posted a selfie from a party together with someone she barely knew, and afterwards did not remember taking the picture. Still, she was "scared of deleting it because of what others might think.” Similarly, Beate tells of a friend who posted a selfie revealing what she (Beate) considers too much naked skin. This resulted in several friends confronting the girl.

Beate: “[W]hen we got together we were like 'why do you have to post pictures like that,' and then we had a nice talk about confidence and looks and stuff."

Elias describes the "courtly art of human observation" as a joint observation of the self and of others in relation to a specific social context (Elias, 1983, pp. 104-106). "This self-observation and the observation of other people are complementary," he writes, "[o]ne would be pointless without the other." We can observe this in how top users police their own presentation in light of how they expect others to respond. Maria (20, Kristiansand) speculates on why her efforts to secure followers occasionally fail.

Interviewer: "Has it happened that people you wish would follow you have unfollowed?"

Maria: "Yes [laughs] If I want to follow them, then it sucks when they don't want to follow me [...] I put so much effort into posting good stuff, so when it's people I know, it really sucks when they 
unfollow me. I mean, it can't be because my pictures are bad, then I would get it, you know? I am really trying to post good pics."

Here, it is not receiving negative feedback that causes frustration, but the sense of being ignored. As in the pre-modern court, visibility is an existential necessity, and recognition of status in the hierarchy depends on being seen and affirmed. Several top users, such as Anne (20) has an app tracking who unfollows her and when.

Anne: “If someone unfollows me, then I unfollow them. I mean, unless they're, like, really big [on Instagram], then I totally get it."

The self-policing does not require actual feedback from followers, only a general fear of being ignored. Ragnhild (19) describes removing a picture she later regretted posting. Her insistence that she does not care what other people say behind her back, and that the decision to delete the post is entirely her own, go together with her explicit awareness that people might disapprove without telling her directly, and that she must maintain a positive attitude in order to be perceived as "inspiring."

Interviewer: "Did you receive any negative response on the post itself?"

Ragnhild: "No, it was my own decision. No one said anything [...] not to my face anyway [...] but probably behind my back, you know.”

Interviewer: "What do you think they say behind your back?"

Ragnhild: “I don’t know. People say so much. I don’t really care anyway. I'm just trying to have a profile that's inspiring to other people, and I try to have a happy tone in what I'm writing. It's important to stay positive."

\subsection{Reproducing the Social Order}

In their seminal study of the town "Winston Parva," Norbert Elias and John L. Scotson describe how local family networks where characterized by unspoken criteria for how people were ranked in social hierarchies. While these criteria are known to everyone in the group, this is not explicit, but primarily on the level of practice (Elias, 1994, p. xxxviii). In our interviews with the top users in Kristiansand's local Instagram clusters, we find a similar dynamic. All our informants demonstrate a high awareness of how Instagram functions according to a logic of status displays, exchange of symbols of 
prestige, mutual policing, and stratification into offline and online hierarchies, even if they might have differing strategies for navigating these logics. ${ }^{9}$

The central question for the present purposes is whether what is associated with prestige in the local clusters corresponds to the symbols associated with "established" groups in Kristiansand. To answer this question, we might look to the symbols circulating in and characterizing particular clusters - such as $\mathrm{C} 5$ the Fitness cluster or C3 and C6, the Fashion clusters. In these typical Instagram genres, top users are typically sponsored by famous brands. Harald, for instance, claims not to care why people often like his posts, but at the same time reveals the degree to which he actively seeks the affirmation of particular brands and people in the fashion world.

\footnotetext{
Harald: “My friends say my Instagram feed is an 'inspofeed,' like an inspiration for others. I don't know about that. I don't think a lot about it [...] But what I often do is tag famous fashion people or where I bought my clothes.”

Interviewer: "In this picture you're enveloped in smoke.”

Harald: "Yes, we bought a smoke bomb [...] and right here, the shop where I bought the trousers have commented on the picture. An emoji. And it's not the first time!"
}

The Fitness Cluster (C5) is another example. Sonja used to post both CrossFit and fashion pictures, but lately she has been "concentrating on the former." She is sponsored by various clothing brands and the Viking CrossFit center, and works out for free as long as she keeps tagging their username in her posts. Erik uses a professional photographer for most of his posts and insists that all his photos are "authentic" because they are taken during actual training sessions.

\subsubsection{Prestigious Consumption}

The clusters also indicate the socio-economic aspirations of the users. One indication is the shops and businesses found among top tagged locations. Here we find mediumto high-end jewelry or fashion outlets (such as Lulu's, Berglihn Goldsmiths, VOLT Sandens, and Bohem) targeting young adults. Other businesses found among the top users across the city as a whole (cluster association in parenthesis) include the music festival and event Palmesus (C0), Hansen \& Co (C3), Bik Bok Sorlandssenteret (C3), Slottet Shopping (C1), and Image (C1). Cross-cluster tagged locations also

\footnotetext{
9 This awareness also manifested in their being confused to be considered a "top user" in the first place; many were initially reluctant to be interviewed because they felt had no reason to be considered "big” on Instagram.
} 
include dining places popular among middleclass consumers, such as the waterfront restaurants at Fiskebrygga (C6), Bønder i Byen (C3), and Jordbærpikene Sandens (C6).

We should note that when locations appear in various forms (such as Flekkerøy, Flekkerøya, Flekkerøy Kristiansand) it suggests that these are not established hashtags, but instead highlights the location itself and its connotations as worthy of display. Some informants speak of actively using Instagram to discover locations recommended by users they admire, whether it be shops, popular hang-outs, or weekend trip destinations. The areas Baneheia and Odderøya (both C7) are popular recreational areas where people go for runs or Sunday walks. In addition, Odderøya is a gentrifying area boasting cafés, museums, art galleries, and occasional music festivals (the Kilden Concert Hall (CO), as well as parts of Fiskebrygga (C6) are located in Odderøya). The area of Flekkerøy(a) is among the top tagged locations in C1, C2, C3, and C8. An island just off mainland Kristiansand, Flekkerøy generally has a more rural feel. It is a popular site for nature photo enthusiasts and is associated with conservative and somewhat charismatic Evangelicalism.

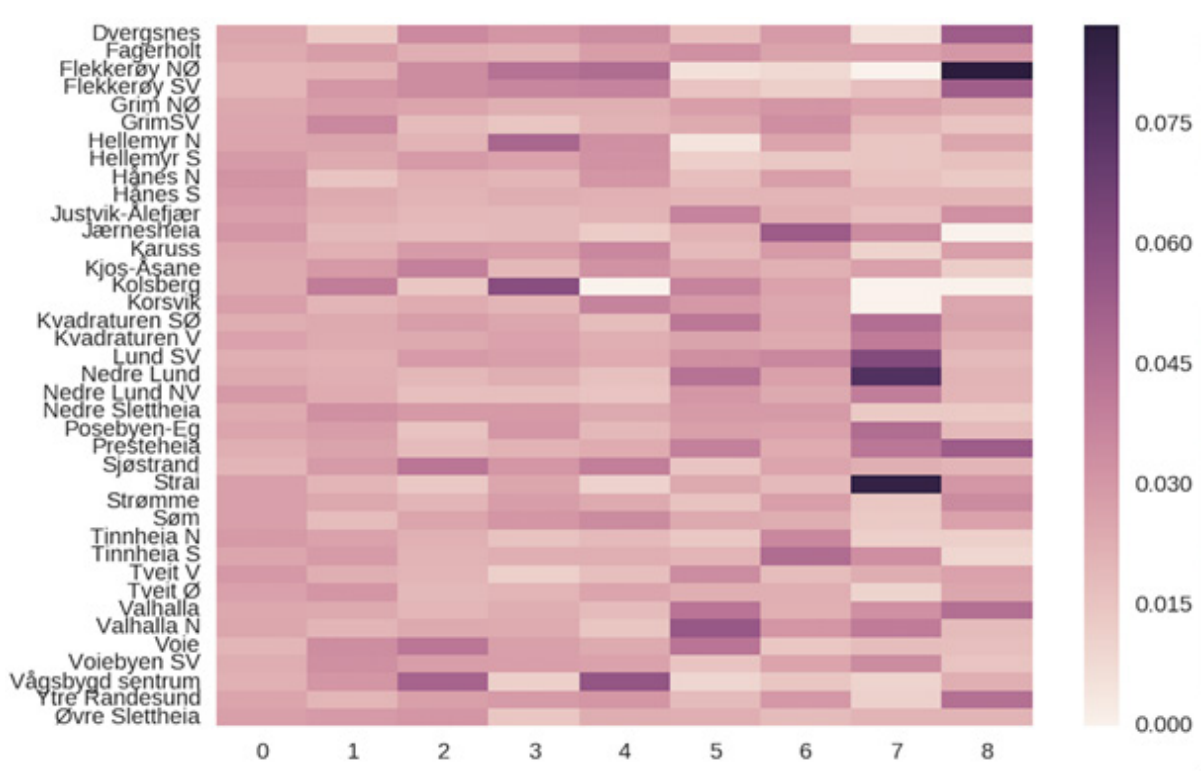

Figure 4.1: Density of clusters according to neighborhood.

The status and prestige associated with the neighborhoods represented in the clusters is further underscored by which areas are not represented. Table II shows the density of clusters in each city neighborhood. Darker colors mean that a higher proportion of posts in the particular cluster was posted from that neighborhood. As is 
evident, CO is evenly spread out across the city's neighborhoods, reminding us that people use Instagram whichever part of the city they live in. The locations appearing prominently in the clusters, however, have important contrasts to the neighborhoods that do not. Flekkerøy, for instance, appears in official statistics as a neighborhood characterized by medium- to upper-medium income levels, relatively low numbers of single parents and unmarried people between 30-49, and with the city's lowest number of immigrant inhabitants (7\%). Relatively low numbers of immigrants also characterize the larger neighborhood of Vågsbygd, which is tagged in clusters C1, C2, C4, C6, and C7.

By contrast, the neighborhoods of Grim, Hånes, and in particular Slettheia, all have very low density of Instagram clusters. According to the numbers from the municipality website, they also have the highest rate of visible ethnic-religious minorities, receivers of welfare, and typically medium- to low-median income levels. What this shows is that people living in neighborhoods with poorer households or a higher rate of visible ethnic-religious minorities might be on Instagram, but they are not included among the top users in the local clusters of online affirmation. Their neighborhoods remain invisible on social media. The point is underscored by the fact that out of all the top users across the clusters, only a handful appear (from their profile photos) to be nonwhite, and of these at least two identify as Christian (as signified in user name, profile picture, or post content), while none are (openly) Muslim.

\subsubsection{City-Wide Symbols of Prestige}

Some symbols of prestige are found across several of the clusters. Here, together with the manual examination of online profiles, the interviews help provide insight into symbols that are circulating more city-wide, at the interface of online and offline communities.

Sports and outdoor life are, as we have seen, associated with high status in Kristiansand's social order. In addition, several of the informants in clusters centering on landscape photography or fashion turn out to be active in various prominent fitness centers and free churches alike. Jon (37), for instance, a top user in the Church cluster is an active member of one of the CrossFit centers prominent in the Fitness cluster. Yet he never posts pictures of himself exercising, because he thinks this would contribute to an unhealthy focus on physical appearance. Still, he mainly follows CrossFit celebrities and instructors from the Viking CrossFit center, where he regularly works out. Jon's own posts feature pictures from the his church's conference center, a few natural landscapes, and him and his family on vacation.

Posts featuring nature and landscape photos are among the top shared and liked across the city - often intersecting with users emphasizing outdoor life as a form of healthy exercise. Some informants post semi-professional photos that have taken a long time to prepare, while others, like Cecilia, edit and post pictures from evening 
walks or weekend outdoor treks. Harald, a top user in one of the fashion clusters, says he enjoys going for walks and posting pictures of "nice scenery." For Beate, whose Instagram profile is prominent both across the city and in the Church cluster, it was nature photos that drew her to Instagram as a social media platform.

Beate: "You know... sunsets draw a lot of likes [laughs] [...] That's what I like, seeing other people's lives and where they are, where they are travelling, and where they are heading."

Finally, the local social order's celebration of nuclear families is reflected and reinforced across the clusters, not primarily because there are many photos of families - though there is arguably a certain prestige associated with displaying a happy family situation - but also in that the family networks of the "established" seem to be reinforced in and across clusters; some of the families enjoying high status in the social order also enjoy high status in the local online hierarchies. For instance, top user Ragnhild belongs to one of Kristiansand's prolific Christian business families, and some of her younger family members have also built up prominent Instagram profiles. These are all found among the top users in the Church cluster, and their connections to recording artists and other influencers in various fields are visible both in post content, likes, and comments. The post that received most likes on Ragnhild's feed features her with some of these family members and famous influencers.

Interviewer: "Why do you think this picture received so many likes?"

Ragnhild: "I don't know. It's got [influencer] in it, and that's fun. And I notice that people like it when I show pictures with my family. That often generates a lot of likes [...] most people know we have a strong family bond, that we are very close and love each other. So, I suppose people [...] want to support that."

Finally, the Christian culture evident in Kristiansand's self-promotion and social order is likewise evident in and across local social media clusters. In terms of content, there is the Christian variation on a common Instagram theme: the inspirational quote on the background of a full teacup, and open landscape, and so on - only here, the quotes are Bible verses. Signs of users identifying with Christianity are also found in usernames, bios, or Christian symbol emojis. More importantly, the interviews reveal networks not immediately visible online. Several informants turn out to also belong to the offline church networks. Cecilia, a fashionista who is one of the most wellconnected users across the city as a whole, does social media work for a large free church, but deliberately avoids Christian symbolism on her own Instagram feed.

Cecilia: “I'd say I go to [church] maybe once a week [...] but [on Instagram] I'm kind of laying low... I mean, I have friends who go there too, but... I follow very few friends. So, I very rarely 'like' pictures of, say, coffee cups with a Bible verse on it [laughs], even if I'm sure I could post pictures like that myself. But, yeah, I don't tend to 'like' those anyway." 
Harald is another case in point. He mainly posts pictures of fashion outfits and is proud of his "inspofeed." He also enjoys administrative access to one of the nature photo hubs in the General cluster which reposts landscape photos from around the region. At the same time, he occasionally volunteers in a large free church's media department - indeed, it was a youth pastor who first recommended Instagram to him. And it was Beate, top user in the Church cluster, who invited him to co-run the landscape photo account.

In summary, while the clusters to some extent make it possible to identify groups according to shared interests - fashionistas, church affiliates, and fitness enthusiasts the clustering does not imply segregation. The General cluster $\mathrm{C} 1$, the largest cluster we have been able to locate, embraces all of these groups. Its top users include the former user profile of a free church's congress center, designers, nature photographers, and fitness enthusiasts. The most locally connected Instagram users in Kristiansand seek to distinguish themselves by displaying symbols of prestige that largely correspond to the ones we have found to characterize the local social order: they picture themselves with family and friends, in nice outfits, at shops or businesses associated with an aspiring middle class, exercising in picturesque natural surroundings, or on their way to church-related activities.

\subsection{Concluding Remarks}

Social media are often assumed to be vectors for social change, for challenging existing structures, and facilitating the forging of new and original identities unhampered by traditional norms. Our evidence points in the opposite direction. Using computational methods in combination with qualitative interviews and participating observation, we have located several social media clusters of users who affirm among themselves certain values and norms through public affirmation in the form of likes, comments, mentions, and so on. Indeed, without computational methods combined with local knowledge and ethnographic sensitivity, these local influencers would have been very difficult to locate, and the meaning of the symbols of prestige they circulate would be near impossible to interpret. Interviews show that top users are aware of the unspoken criteria for rising in the online as well as offline social ranks, and these criteria largely correspond to the symbols of prestige we were able to define in the social order of the city. Where one might have thought that social media would level the playing field between diverse groups in a medium-sized city, what we see is the reproduction of a social order where one group tends to dominate other groups in terms of visibility and influence. 


\section{References}

About Cultiva. (2017, November 9). http://cultiva.no/english/

Abrahamsen, O. A. (2014). Kristenredere og småbymatadorer. In S. Bjørg (Ed.), Agderseminaret 2013: Religion og næringsliv (pp. 112-135). Cappelen Damm Akademisk.

Benkler, Y. (2007). The Wealth of Networks: How Social Production Transforms Markets and Freedom (9/23/07 edition). Yale University Press.

Bille, T. (2013). How to Develop a Region Through Culture and Creativity: The Foundation Cultiva in Kristiansand. In L. Lindeborg \& L. Lindkvist (Eds.), The Value of Arts and Culture for Regional Development: A Scandinavian Perspective (pp. 161-179). Routledge.

Botvar, P. K. \& Aagedal, O. (2002). Øst er øst og vest er vest...? En sammenligning av østnorsk folkekristendom og sørvestnorsk vekkelseskristendom. In O. G. Winsnes (Ed.), Tallenes tale 2002 Kifo-rapport nr 23. Tapir Akademisk.

Botvar, P. K., Repstad, P., \& Aagedal, O. (2010). Regionaliseringen av norsk religiøsitet. In P. K. Botvar \& U. Schmitt (Eds.), Religion i dagens Norge. Universitetsforlaget.

Castells, M. (2008). The New Public Sphere: Global Civil Society, Communication Networks, and Global Governance. The ANNALS of the American Academy of Political and Social Science, 616(1), 78-93. https://doi.org/10.1177/0002716207311877

Elias, N. (1978). What is Sociology? (S. Mennell \& G. Morrissey, Trans.). Columbia University Press.

Elias, N. (1983). The Court Society (E. Jephcott, Trans.). Pantheon Books.

Elias, N. (1994). The Established and the Outsiders. Sage Publications.

Halvorsen, A. (2004). Hvor spesielle er sørlendingene? En analyse av kristen tro og aktivitet i Vest-Agder. In O. G. Winsnes (Ed.), Tallenes tale 2004: Perspektiver på statistikk og kirke. Tapir Akademisk.

Hundstad, D. (2008). Regionsbygging i sør. In B. Seland (Ed.), Regionen (pp. 59-92). Høyskoleforlaget.

Johnsen, B. E. (2010). Skippere, sommergjester og Sabeltann. In B. E. Johnsen (Ed.), Sørlandsk kultur (pp. 37-68). Høyskoleforlaget.

Justvik, N. M. (2012). Idrett og Kristendom på Sørlandet: 1945-2000. Portal Akademisk.

Kommunedelplan idrett- og friluftsliv, 2015-2018. (2014). Kultur- og idrettsetaten.

Lysgård, H. K. (2013). The definition of culture in culture-based urban development strategies: Antagonisms in the construction of a culture-based development discourse. International Journal of Cultural Policy, 19(2), 182-200. https://doi.org/10.1080/10286632.2011.647005

Lysgård, H. K. \& Tveiten, O. (2005). Cultural economy at work in the city of Kristiansand: Cultural policy as incentive for urban innovation. AI \& SOCIETY, 19(4), 485-499. https://doi. org/10.1007/s00146-005-0334-5

Magnussen, M.-L., Mydland, T. S., \& Kvåle, G. (2005). Arbeid ute og hjemme: Sørlandske mødres valg og vurderinger (FoU-Rapport No. 5). Agderforskning.

Magnussen, M.-L., Repstad, P., \& Urstad, S. (2013). Skepsis til likestilling på Sørlandet - et resultat av religion? Tidsskrift for Kjønnsforskning, 36(03-04), 204-222.

Røed, H. (2010). Sørlandet - et politisk “annerledesland.” In B. E. Johnsen (Ed.), Sørlandsk kultur: Mangfoldet og motsetningene (pp. 146-197). Høgskoleforlaget.

Ryen, A. (2002). Husmorlandets siste skanse. In K. Jon P. \& S. Hege (Eds.), Hvitt stakitt og fiberoptikk: Regionale myter - regional makt (pp. 167-183). Høyskoleforlaget.

Seland, B. (2012). Sørlandsk pietisme? Religion på tvers av grenser. In B. E. Johnsen (Ed.), Sørlandet og utlandet (pp. 91-120). Cappelen Damm Akademisk.

Seland, B. (2014). Den kristelige gründeren: Sosiale kapital og hard valuta. In S. Bjørg (Ed.), Agderseminaret 2013: Religion og næringsliv (pp. 89-111). Cappelen Damm Akademisk. 
Stanley, L. (2016). The Established-Outsider Figuration, Race and Whiteness [Educational]. Whites Writing Whiteness: Letters, Domestic Figurations \& Representations of Whiteness in South Africa 1770s-1970s. http://www.whiteswritingwhiteness.ed.ac.uk/thinking-with-elias/ the-established-outsider-figuration-race-and-whiteness/ 